\title{
O poder constituinte e a força
}

\section{João Quartim de Moraes}

O argumento da força na história da República: da "manutençāo das leis" à "ameaça interna"

Em suas amargas diatribes contra o regime que acabara de se instaurar no Brasil através do golpe militar de 15 de novembro de 1889, Eduardo Prado previu para a antiga América portuguesa destino análogo ao que conhecera a antiga América espanhola: a secessão e o caudilhismo. É que, como insiste ao longo de Fastos da Ditadura Militar no Brasil'1, nosso país só escapara, em suas quase sete décadas de existência independente, dos descaminhos em que se embrenharam os outros povos ibero-americanos graças ao princípio monárquico, que lhe assegurara tanto a unidade política quanto as liberdades civis.

Embora a primeira de suas previsōes não se tenha verificado e a segunda apenas parcialmente (afinal, com uma só interrupção - a presidência do marechal Hermes da Fonseca - os grandes agrários de Sāo Paulo e de Minas Gerais asseguraram, à sua maneira, o "controle civil" do poder político), Eduardo Prado detém o mérito de ser o pioneiro na crítica das instituiçōes e do exercício do poder republicano no Brasil: o primeiro dos seis artigos reunidos em Fastos da Ditadura Militar no Brasil - "Os acontecimentos do Brasil" - é datado de 30 de novembro de 1889 , tendo sido publicado no número de dezembro de 1889 da Revista de Portugal ${ }^{2}$. Monarquista liberal, aflige-o sobretudo, embora não se exprima com a lógica contundente de um Edmund Burke, a erupção da demagogia e das paixões irracionais conseqüente à quebra do princípio de legitimidade encarnado na Coroa. "Os terroristas franceses apoiavam-se no concurso dos Clubes e das Seçōes; os jacobinos militares do Brasil recebem o aplauso dos sectários rancorosos e dos seus prosélitos da última hora..." (FREDERICO de S., 1890, p. 43). A comparação com o terror jacobino na Revolução Francesa é menos importante, entretanto, em sua argumentaçāo, do que com os "exércitos de opereta" como o peruano, coberto "de plumas e de galões", habituado a "salvar a pátria todos os dias", sempre pronto a "aclamar generalíssimos", mas desbaratado sem glória pelos "voluntários chilenos" (id. ibid., p. 83). Antecipando, neste ponto, uma interpretação que será aceita amplamente por sociólogos políticos de inspiração liberal, por exemplo o norte-americano Samuel

1 Publicado em Portugal, 1890, em cima dos acontecimentos, sob o pseudônimo de Frederico de S.

2 Tão pioneiras quanto as críticas de Eduardo Prado foram as reportagens de Max Leclerc, enviado ao Brasil pelo Journal des Débats, que as publicou sob o título de Lettres du Brésil ao longo de 1890,e, neste mesmo ano, com o mesmo título, sob forma de livro (Paris, Plon). Como é costume, optamos por modernizar a ortografia de Eduardo Prado. 
Huntington ${ }^{3}$, Eduardo Prado associa apoliticismo à eficiência militar e, correspondentemente, intervencionismo político à falta de qualidades bélicas. $\mathbf{O}$ argumento é, portanto, o seguinte: a quebra da legitimidade tradicional (a monarquia) instaura o reino da força e por conseguinte, de imediato, ou após algumas mediaçōes demagógicas, o reino do mais forte, a saber, a ditadura militar. $\mathrm{Na}$ Revolução Francesa, uma década separa a queda da Bastilha da fulgurante ascensāo de Bonaparte. No Brasil, Deodoro chegou primeiro à Presidência e lá ficou: o jacobinismo militar brasileiro reuniu, numa so fase, aquilo que na versāo histórica paradigmática francesa reclamou quatro regimes políticos e outras tantas constituiçōes (monarquia constitucional codificada na Constituiçāo de 3 de setembro de 1791; ditadura revolucionária jacobina, codificada na Constituição de 24 de junho de 1793; república moderada, codificada na Constituição de 5 frutidor ano III - 22 de agosto de 1795; Consulado, codificado na Constituição de 22 frimário ano VIII - 13 de dezembro de 1799).

A própria argumentaçāo de Fastos da Ditadura Militar no Brasil mostra que a dedução da ditadura militar a partir da ruptura da legitimidade monárquica deve ser entendida em sentido estrito. Não é exatamente a queda da monarquia, mas a crise de legitimidade provocada por esta queda que conduz ao "jacobinismo militar". Refutando a doutrina do "soldado-cidadâo", efemeramente guindada, por Benjamin Constant e seus amigos, às altas esferas do governo federal, Eduardo Prado observa que "onde nāo há obediência passiva, surge logo o militar político, entidade cuja presença num país é o mais seguro indício do atraso de sua civilização. A República Argentina tem realizado os seus admiráveis progressos destes últimos dez anos, porque o militar político é criatura que naquele país parece já pertencer à história" (FREDERICO de S., 1890, p. 299). O mal nāo está, portanto, nas instituiçōes republicanas enquanto tais, mas na politizaçāo dos militares. Despolitizando-0s, a República Argentina ingressará, na penúltima década do século XIX, num periodo de "admiráveis progressos". Quanto à relação de causa e efeito entre a "obediência passiva" dos militares às autoridades legítimas e sua eficiência profissional, o exemplo chileno é fortemente enfatizado: "O oficial chileno, ainda orgulhoso da gloriosa campanha em que o exército nacional levou de vencida as tropas veteranas dos 'pronunciamientos' peruanos e bolivianos, tem o mais nobre desprezo pelo oficial que pretende servir-se da sua espada em favor da sua opinião política" (id. ibid., p. 300).

Seria difícil, lendo estas linhas redigidas há quase um século, deixar de pensar nos Videla, Pinochet e consortes. Mas, longe de invalidar as apreciaçōes dos "Fastos...", a recrudescência do intervencionismo militar em nossos tempos as confirma. No caso argentino, da maneira a mais contundente: os torturadores da guerra suja foram desbaratados numa guerra limpa pelas tropas profissionais de Sua Majestade Britânica... De modo geral, constatamos estarem correla-

3 As teses de Samuel Huntington estăo expostas notadamente em The Soldier and the State: the theory and politcs of civil-military relations $\mathrm{e} e m$ "Civilian Control of the Military: a theoretical statement". In: Political Behavior: a reader in theory and research. (Obra coletiva). Foi, sobretudo, atraves da sintese destas teses efetuadas por Alfred Stepan em seu "The New Professionalism of Internal Warfare and Military Role Expansion" que as idGias de Huntington penetraram no debate em torno das func6es dos militares na América Latina. O referido estudo de Stepan está em Authoritarian Brazil (obra coletiva, New Haven and London, Yale University Press, 1973) e sua sintese das teses de Huntington sobre o profissionalismo militar é tratada no tópico inicial do tex to ("Conflicting Paradigms: new professionalism vs. old professionalism", p. 47-53), onde o leitor encontrará no corpo do texto e nas notas as referencias completas as passagens pertinentes na obra de Huntington.
.. Eduardo Prado associa apoliticismo à eficiencia militar e, correspondentemente, intervencionismo polftico à falta de qualidades belicas. (...) sob o rótulo de "doutrina da segurança nacional" erigiu-se em ideologia do controle militar do Estado sobre a sociedade. 
cionadas a tendência à "intervenção interna" das Forças Armadas e a redução da perspectiva de uma agressão externa. Não se trata, evidentemente, de uma simples relação de causa a efeito. Por si só, a redução da "ameaça externa" não conduz a nenhum efeito predeterminado. A priori, poder-se-ia mesmo supor que o efeito mais plausível, ou pelo menos mais racional, consistiria na correspondente redução dos gastos e dos efetivos militares. É claro, portanto, que o fenômeno a que temos assistido, entre nós e alhures, da reconversão para o plano interno da função militar, obedece a um complexo de fatores, dentre os quais a percepção da ausência de ameaças externas ponderáveis não é necessariamente o mais importante. Ela se tornou importante, na América Latina, ao ser associada a uma percepçâo complementar, a de que o inimigo eram as forças subversivas internas, portadoras, como repetiam ad nauseam nossos generais, de "ideologias exóticas e subversivas, contrárias à formação cristã e democrática de esmagadora maioria de nossa população". A concepção estratégica em que se fundamentava esta percepção, abstração feita de seu conteúdo paranóico, dispensa apresentações: sob o rótulo de "doutrina da segurança nacional" erigiu-se em ideologia do controle militar do Estado sobre a sociedade.

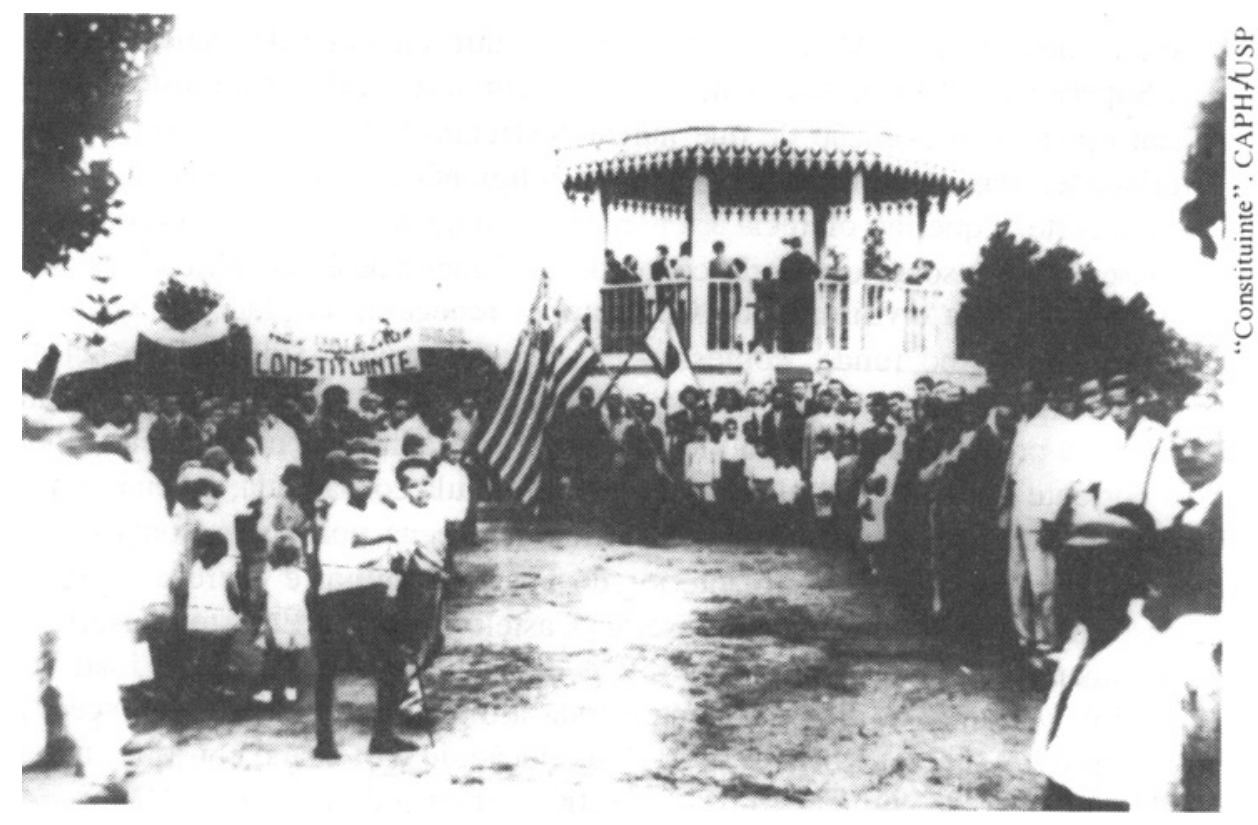

Uma percepção deixa de ser categoria meramente subjetiva e, portanto, de ser objeto exclusivo da análise psicológica quando é coletivamente assumida por um corpo social e, a fortiori, por uma corporação estatal como a militar. Atingindo esta dimensão, o componente psicologico cede lugar ao político. Do mesmo modo que seria pueril reduzir a explicação do nazismo às frustrações e fobias de Adolf Hitler e de seus fâmulos, não se poderia, sem simplificação excessiva, reduzir a doutrina e o regime "de segurança nacional" às obsessōes $\mathrm{e}$ delírios conspiratórios de seus ideólogos. Que se percorra um dos textos canônicos desta escola de pensamento, a muito citada Geopolítica do Brasil do general Golbery do Couto e Silva. O leitor armado da paciência necessária para atravessar as longas digressōes geodésicas e cartográficas às quais recorre compulsivamente o autor, na obstinada tentativa de deduzir da "geopolítica" uma ideologia, uma estratégia e um destino histórico - na linguagem do gene- 
ral: os objetivos nacionais permanentes -, encontrará formulaçōes lúcidas e suficientemente conseqüentes para deixar transparecer, no enunciado dos postulados doutrinários, o surdo conflito entre as imposiçōes estratégicas da "segurança nacional" e os valores que pretensamente teria a vocação de preservar. $\mathrm{Na}$ estratégia da guerra fria, o Ocidente "luta com desvantagens evidentes" contra o comunismo, a principal das quais é a de ser "uma sociedade democrática, aberta à infiltração da propaganda inimiga e que, respeitando a consciência do indivíduo e a dignidade da pessoa humana, nāo pode reprimir com eficácia a atuaçāo desagregadora da quinta-coluna soviética, dos simpatizantes e teleguiados comunistas" (COUTO e SILVA, 1967, p. 244). Reconhecemos aqui, sem dificuldade, o argumento banal, mas nem por isso menos carregado daquele sombrio zelo inquisitorial que, para reprimir com mais eficácia os inimigos do Ocidente - nāo deve haver liberdade para os inimigos da liberdade -, levaria, de escalada em escalada, de golpe militar em golpe militar, da criação do SNI à organizaçāo dos DOI-CODI. Se o general Golbery tivesse se limitado a retomar este argumento, lugar-comum daquele estilo de anticomunismo militante que se costuma designar abrasileiradamente por macartismo, seu interesse para a história política de nosso país seria pequeno. Não seria, com efeito, maior do que o de um coronel Meira Matos ou de qualquer outro ideólogo de plantão da Escola Superior de Guerra, dos quais só não se dirá terem caído num justo esquecimento pela simples razão de que nunca desfrutaram nem mesmo de efêmera notoriedade. Mas, contrariamente a seus correligionários, não se contentou com a opaca certeza que lhe oferecia a reiteraçāo do dogma macartista. Avaliou-lhe as conseqüências sobre o próprio conteúdo da "liberdade democrática", "valor inestimável para a civilização do Ocidente": "renegá-la, em face do agressor totalitário, seria, no fundo, confessar-se a priori vencido" (id. ibid., p. 244). Escritas originalmente em 1958, estas linhas antecipam, numa curiosa ironia histórica, a própria trajetória política do autor, que coincide, no essencial, com a da corrente política da qual foi, segundo a fórmula consagrada, a "eminência parda": o castelismo. Ela surgiu e se afirmou na cena política nacional como contra-revolução articulada no interior do aparelho militar e exerceu o poder político diretamente (através dos generais Castelo Branco e Emesto Geisel) ou indiretamente (durante os governos dos generais Garrastazu Medici e João Figueiredo), portanto, ao longo de quase toda a ditadura militar, com a exceção do governo do general Costa e Silva. A evolução do castelismo constitui, nesta medida, a chave da compreensão da dialética perversa do argumento da força e da força do argumento na história política do Brasil contemporâneo.

Esta evolução se deixa resumir em três momentos: a "percepção da ameaça"; sua supressão pelo ato de força de 31 de março de 1964; a supressão desta supressāo através da "abertura política" orquestrada pelos genarais Golbery e Ernesto Geisel, ou, retomando a linguagem daquele: o Ocidente ameaçado pelos inimigos da liberdade (os comunistas); o Ocidente suprimindo a liberdade para melhor combater os inimigos da liberdade (golpe e ditadura); o Ocidente liberalizando para não se negar como Ocidente (abertura "gradual e controlada"). Trata-se de uma dialética perversa no duplo sentido (material e formal) da expressão. No sentido material, pela razão evidente de que a passagem da força do argumento ( a doutrina da segurança nacional) para o argumento da força (golpe, ditadura) constitui aquela forma de violência que, conforme Eduardo Prado, inspirava ao oficial chileno de seu tempo "o mais nobre desprezo":
A evolução do castelismo constitui, nesta medida, a chave da compreensão da dialética perversa do argumento da força $e$ da força do argumento na historia política do Brasil contemporâneo. 
"servir-se da sua espada em favor da sua opinião política". Com a agravante de que, aplicada às sórdidas atrocidades meticulosamente praticadas pela OBAN e pelo DOI-CODI, a metáfora da espada soa como delicado eufemismo. No sentido formal, por se tratar de uma dialética sem síntese efetiva, vale dizer, cujo terceiro momento se resolve no retorno ao primeiro momento, a saber, o da "segurança nacional", com o alerta (às vezes sanguinário, como no massacre de Volta Redonda em novembro de 1988) contra os inimigos da liberdade, guerrilheiros urbanos e outros subversivos. Não havendo síntese, há portanto repetição. Encontramo-la em todas as instâncias do poder político onde se definem as atribuições do aparelho militar do Estado e, notadamente, nos textos constitucionais. Como foi amplamente ressaltado em estudos sobre 0 assunto, suscitados pelos debates em torno da Constituição promulgada a 5 de outubro de 1988, esta repete, com modificações superficiais, os dispositivos das Constituiçōes precedentes relativos às funçōes dos militares, retomando todas, senāo a fórmula ipsis litteris, com certeza a concepção político-institucional do artigo 14 da Constituição de 1891 redigido por Rui Barbosa: “As forças de terra e mar são instituiçōes nacionais permanentes, destinadas à defesa da pátria no exterior e à manutenção das leis no interior" 4 . Sem dúvida, manter as leis não é o mesmo que aplicá-las, nem, menos ainda, que formulá-las. Mas nem a argúcia da "águia de Haya" poderia nos convencer que este dispositivo constitucional, hobbesiano malgré lui lembora não seja uma referência teórica do ilustre jurista baiano, o Leviatâ, dois séculos antes, já condicionara a vigência da lei à força da espada) não sacramenta o princípio da intervenção militar na coisa pública.

Ora, a norma jurídica em que o argumento intervencionista está cristalizado não se coaduna com a inspiração liberal da Constituição de 1891 e das Constituiçōes seguintes, inclusive aquelas de 1967 e 1969, outorgadas por um poder discricionário e ilegítimo. As filosofias políticas liberais e democráticas não admitem sequer a existência de uma função de "manutenção das leis" distinta das funçōes de legislar, de executar as leis e de julgar a adequação das leis aos casos concretos. As leis se mantêm, nesta perspectiva, na medida em que são executadas e aplicadas. Levar-nos-ia muito longe retomar, ainda que esquematicamente, a evolução da teoria dos poderes de Estado nos textos clássicos da teoria política. Notaremos apenas que tanto a vertente que, de Bodin a Rousseau, contrapõe o poder soberano de legislar ao poder subordinado de governar, isto é, de executar as leis, quanto aquela que, a partir de Locke e de Montesquieu, distingue três poderes (respectivamente legislativo, executivo e federativo; e legislativo, executivo para as coisas que dependem do direito das gentes e executivo para as coisas que dependem do direito civil, este correspondendo ao executivo de Locke e aquele ao federativo) entendem por execução das leis sua aplicação efetiva aos casos concretos e, portanto, suá "manutenção". Quanto ao poder real, neutro ou moderador, introduzido no século XIX por Benjamin Constant, o fato de ter sido invocado, com finalidades apologético-doutrinárias, para justificar o intervencionismo militar em nosso país, a

4 Sobre o precedente aberto pelo mencionado artigo 14 da Constituiçāo de 1891 , o comentário mais documentado juridicamente, já que reúne, numa perspectiva comparativa, todos os textos constitucionais, até o de 1969, relativos à posiçâo das Forças Armadas na sistemática das Constituiçōes, ao recrutamento militar, ao caráter organizatório das corporaçóes armadas do Estado, às suas funçōes, às suas relaçốes com o Estado, as formas de sua subordinaçäo as autoridades políticas e, enfím, à definiçāo da autoridade polftica suprema a quem devem obediencia, $€$ o de Oliveiros Ferreira, "As Forças Armadas na Constituiçấo", 1985, p. 391 -436. Um comentário muito pertinente $\mathcal{E} 0$ de Wilma Peres Costa, "Os militares e a primeira Constituição da República", 1987, p. 38-41. 
partir de duvidosa analogia entre o poder do Imperador e o dos militares na República, constitui uma dupla mistificação, do ponto de vista do ideário liberaldemocrático no qual pretendem se situar seus apologistas e doutrinários ${ }^{5}$.Em seu sentido próprio, não passa de um elenco juridicamente desconexo de atribuições discricionárias outorgadas a um Imperador que, sem chegar a ser um monarca absoluto (Pedro I bem que o tentou, mas sem sucesso), tampouco pode ser considerado como um monarca constitucional no sentido inglês do termo. Em seu sentido figurado (o "poder moderador dos militares") a mistificação é ainda mais tosca sobretudo quando, como ocorre no conhecido The Military in Politics, de Alfred Stepen, vem revestida de uma roupagem científica. $O$ "poder mantenedor" das Forças Armadas não passa um enxerto autocrático no corpo constitucional liberal. Sintomaticamente, a Carta criptofascista de 1937 foi a única que, sem abandonar o sempre repetido princípio intervencionista, modificou notavelmente a caracterização das condiçōes de sua aplicação: estipula, com efeito, em seu artigo 166 que, ao se tornar "necessário o emprego das Forças Armadas para a defesa do Estado, o Presidente da República declarará em todo o território nacional, ou parte dele, o estado de guerra". A ditadura do Executivo estadonovista dispensava hibridismos ideológicos: a manutenção das leis (a defesa do Estado) se efetuava manu militari, mas subordinada ao arbitrio do Ditador. A Constituiçāo liberal de 1946 restabeleceu, com a separação dos poderes, o caráter estritamente militar do "poder mantenedor"6, retornando, portanto, ao tradicional hibridismo institucional de nossa história republicana: um Estado liberal militarmente tutelado. Em 1891, entretanto, ainda não se podia falar em tradiçâo intervencionista, nem mesmo numa vontade clara de instaurá-la. Os apologistas da Constituição então adotada, como o jurista d'Alencastro Autran ${ }^{7}$, sequer vislumbram no artigo 14 qualquer perigo intervencionista: tratar-se-ia apenas de "fazer triunfar a sociedade dos obstáculos que a execução das leis poderia encontrar na oposiçāo das vontades individuais". Tomado literalmente, o comentário é constrangedoramente tolo: quem executa as leis é o Executivo enquanto tal e não um de seus órgãos em particular. Acresce que se o obstáculo à execução das leis provém de "vontades individuais", o órgão do Executivo, ao qual cabe assegurar seu cumprimento, é a polícia e não o Exército ou a Armada. Mas não seria exatamente para esta confusão de funçōes que apontava o canhestro hermeneuta, reconhecendo, malgré lui, que atribuir aos militares a "manutençāo das leis" implicava em transformá-los em policiais?

De antemão, no entanto, o Exército recusara, com indignação, um baixo trabalho policial: em outubro de 1887 , numa resolução ${ }^{8}$ adotada em assembléia

5 Como mostramos no estudo "Alfred Stepan e o mito do poder moderador", Fulosofia Palítica, (2): 163-99, 1985.

6 Assım o estipula o artigo 177 da Constituiçāo de 1946: "Destinam-se as Forças Armadas a defender a Pátrı e a garantir os poderes constitucionais, a ordem e a lei".

7 Autor de uma edição comentada da Constiturçāo de 1891 publicada, no Rio de Janeiro, por Laemmert e C. Editores, 1892.

$\mathbf{s}$

Consultamos duas transcriçóes do texto da Resolução antiescravocrata do Clube Militar: Magalhães Junıor, "O Aprendiz de Feitıceiro", 1957, v, 1, p. 317-18 e Estado Maior do Exército, História do Exército Brasileiro, 1972, p. 672-73. Está viva em nossa memória a triste ironia de Volta Redonda: quando se comemorava ưm século de Aboliçăo, aquele mesmo Exército, que tão dignamente contribuira para suprimir da sociedade brasileira a nódoa infamante da escravidăo, tomava de assalto as instalaçooes da Companhıa Siderúrgica Nacional com mortffera truculência. Rea tiva-se, assim, na "Nova República", aquele estilo de pacificação cujo paradigma $₫$ a paz dos cemiterios. 
do recém-fundado Clube Militar, assinada por seu presidente, o marechal Deodoro da Fonseca, os oficiais presentes suplicavam à Regente Dona Isabel que lhes poupasse a desonrosa incumbência de caçar escravos fugitivos, vale dizer, de assegurar a manutenção de leis odiosas. A linguagem comedida realça ainda mais a sinceridade do apelo. O contraste entre esta postura socialmente generosa dos oficiais fundadores do Clube Militar e o mórbido complexo anti-sindical que se cristalizou, ao longo do último meio século, na mentalidade dos oficiais de nossas Forças Armadas (e não só das nossas), dá a medida da desoladora inversāo de valores operada à sombra da manutenção da lei e da ordem. 0 episódio era demasiado recente para que os constituintes de 1890-91 não o tivessem presente no espírito. Sem dúvida, a Abolição tornara-o anacrônico, mas justamente por isso dera razāo retrospectivamente aos oficiais abolicionistas. Por que razão, então, conferir o caráter de atribuição constitucional a uma função que os militares, poucos anos antes, haviam solenemente declarado ser estranha a seus deveres profissionais? Responder a esta questão é examinar as motivações políticas do autor da malsinada fórmula: o que teria levado o futuro candidato civilista à presidência da República a patrocinar juridicamente 0 intervencionismo militar? E de se excluir, desde logo, qualquer preocupação com o inimigo interno. Não que a República nascente não os tivesse: ultrafederalistas e monarquistas prepararavam-se, no Rio Grande do Sul e na Esquadra, para atear o fogo da guerra civil, que eclodiria em 1892 e prosseguiria até o fim do mandato de Floriano Peixoto. Mas, obviamente, não se tratava do mesmo gênero de inimigo que mais tarde seria definido pela ESG e combatido pela OBAN e pelos DOI-CODI com seus métodos peculiares. A intenção de Rui Barbosa ao instituir o "poder mantenedor" não era, em absoluto, a de especializar os militares no que mais tarde seria chamado de "combate à subversão". Cometeríamos, de resto, um evidente anacronismo se buscássemos no contexto histórico da proclamação da República qualquer preocupação sistemática neste sentido: a noção de "segurança interna" simplesmente não existia naquela época. No entanto, o cuidado metodológico para não amalgamar anacronicamente categorias jurídico-políticas cujo conteúdo remete a situaçōes históricas distintas não deve fazer perder de vista sua dimensāo diacrônica, vale dizer, no caso, o destino que teria, em nossa cultura política, a vinculação constitucional dos militares "à manutenção das leis no interior". Metodologicamente, portanto, trata-se simplesmente de integrar o ponto de vista sincrônico (a significação historicamente originária do "poder mantenedor") com o ponto de vista diacrônico (sua significaçāo enquanto justificaçāo do intervencionismo militar em nossa história) de maneira que, identificada aquela significaçāo originária do peculiar instituto constitucional, possamos descrever sua evolução enquanto dialética sem síntese do "argumento da força" na história da República.

A ditadura do

Executivo estadonovista dispensava hibridismos ideol6gicos: a manutenção das leis (a defesa do Estado) se efetuava munu milturi, mas subordinada ao arbítrio do Ditador.
Ditadura, Constituição e soberania popular: exame comparativo dos processos constituintes de 1890-1891 e 1986-1988

A fórmula canônica dos manuais de história pátria, de que o marechal Deodoro proclamou a República, é uma maneira elegante de assinalar que a República, entre nós, nasceu de um golpe militar. Os monarquistas, em sua condição de partidários do regime derrubado, não estavam sujeitos às mesmas normas de etiqueta: classificaram imediatamente a nova ordem institucional do 
País como ditadura militar. Naquela época, de resto, o vocabulário político era. mais franco: os positivistas preconizavam abertamente, como se sabe, uma "ditadura republicana" ou "ditadura progressista"9 (expressão utilizada por Benjamin Constant em reuniōes do Governo Provisório); Floriano Peixoto, em julho de 1887, sustentara, em carta ${ }^{10}$ a um amigo, a necessidade de uma "ditadura militar" para "expurgar este pobre País", assolado pela "podridão" e o marechal Deodoro se apresentava, nos decretos presidenciais outorgados até a promulgação da Constituição, como "chefe do Governo Provisório, constituído pelo Exército e Armada"11: na delicada semântica do verbo constituir é difícil saber se, no caso, seu sentido é meramente genético ou estrutural... Na obra Deodoro, a Espada contra o Império de Magalhães Junior (1957) vem reproduzida a rude tomada de posição do marechal Deodoro em reunião do Ministério efetuada a 14 de novembro de 1890 , tal como registrada em ata: "Quis, no primeiro ano desta ditadura, proceder contra o meu temperamento e ser brando e conciliador... Quando, porém, é preciso, sei ser enérgico..." (MAGALHÃES JUNIOR, 1957, v. 2 p. 229). No dia seguinte, respondendo à delegação enviada para saudá-lo pelo Congresso Constituinte, que acabara de realizar sua sessão inaugural, Deodoro bateu na mesma tecla: "Sopitando às vezes a impetuosidade do próprio sentimento pessoal procurei constituir uma ditatura de paz e harmonia..." (id., ibid., p. 233). Sobre o significado da fórmula "constituído pelo Exército e Armada", aplicada ao "Governo Provisório", vale dizer, que ele se assumiu como estruturalmente militar - como composto de militares. Numa decisão que alimentou o sarcasmo de seus críticos, todos os ministros civis de Deodoro foram agraciados com a patente de general de brigada.

Para o analista político, entretanto, nem o fato (incontestável) de que a República nasceu de um golpe militar, nem a retórica dos adversários do novo regime, nem o culto positivista da ditadura republicana esclarecida configuram provas históricas de que o turbulento período dito da "consolidação da República", que vai de sua proclamação à posse de Prudente de Morais, isto é, de 15-11-1889 a 15-11-1894, deve se caracterizar como uma ditadura militar ou mesmo como uma ditadura tout court, ao menos no sentido que conferimos contemporaneamente à expressão. Sem dúvida, a noção de "ditadura", semanticamente muito fluida, está saturada de conotaçôes polêmicas, sendo difícil, sem cair no pedantismo, propor-lhe uma definiçāo que apresente marca registrada de cientificidade. Já os grandes fundadores da Filosofia Política Moderna, Maquiavel e Hobbes, haviam ironizado a propósito das caracterizações valorativas dos regimes políticos: aquele observando que "nenhuma precaução pode impedir" que um regime considerado bom degenere em seu contrário, "tão grande nesse assunto pode ser a semelhança entre o bem e o mal"; este notando que termos como "tirania e oligarquia" não constituem "nomes de outras formas de governo, e sim das mesmas formas quando são detestadas"12. Sem partilharmos da concepção instrumental e nominalista da linguagem política sobre a qual repousam estas ironias, isto é, sem sustentarmos que ditadura é o nome

\footnotetext{
9 Sobre a “ditadura progressista" cf. Magalhães Junior, “O Galo na Torre”, 1957, v. 2, p. 169.

10 A carta contendo o desabafo de Floriano Peixoto está reproduzida em Hélio Silva, A Repúhlica não esperou o amanhecer, 1972, p. 194-95.

11 Sobre as fórmulas dos decretos do Governo Provisório cf. Magalhães Junior, op. cit., p. 179.

12 Cf. Maquiavel, Duscurso sobre a primeira década de Tito Livio, 1, 2 e Hobbes, Leviatã, 11, 19.
} 
que damos aos governos de que não gostamos, há de se convir que elas apontam para o elemento irredutivelmente polêmico de todo jutzo político e, em última análise, para o elemento de força presente em todo poder político. Nesse sentido, evidentemente, a instauração da República, como ocorre em qualquer ruptura institucional, constituiu um ato de força, imediatamente caracterizado como ditatorial por aqueles sobre os quais esta força incidiu, no caso, os monarquistas. Significativamente, no entanto, foi também caracterizado como tal, embora não exatamente no mesmo sentido do termo, tanto pelos inspiradores positivistas do golpe republicano quanto pelo próprio chefe do Governo Provisório, com a diferença de que aqueles valorizavam o principio da ditadura meritocrática fundada na competência "científica" dos detentores do poder político, ao passo que, para Deodoro, a ditadura justificava-se apenas como forma provisória do poder republicano, até a instauraçāo de suas instituições legítimas.

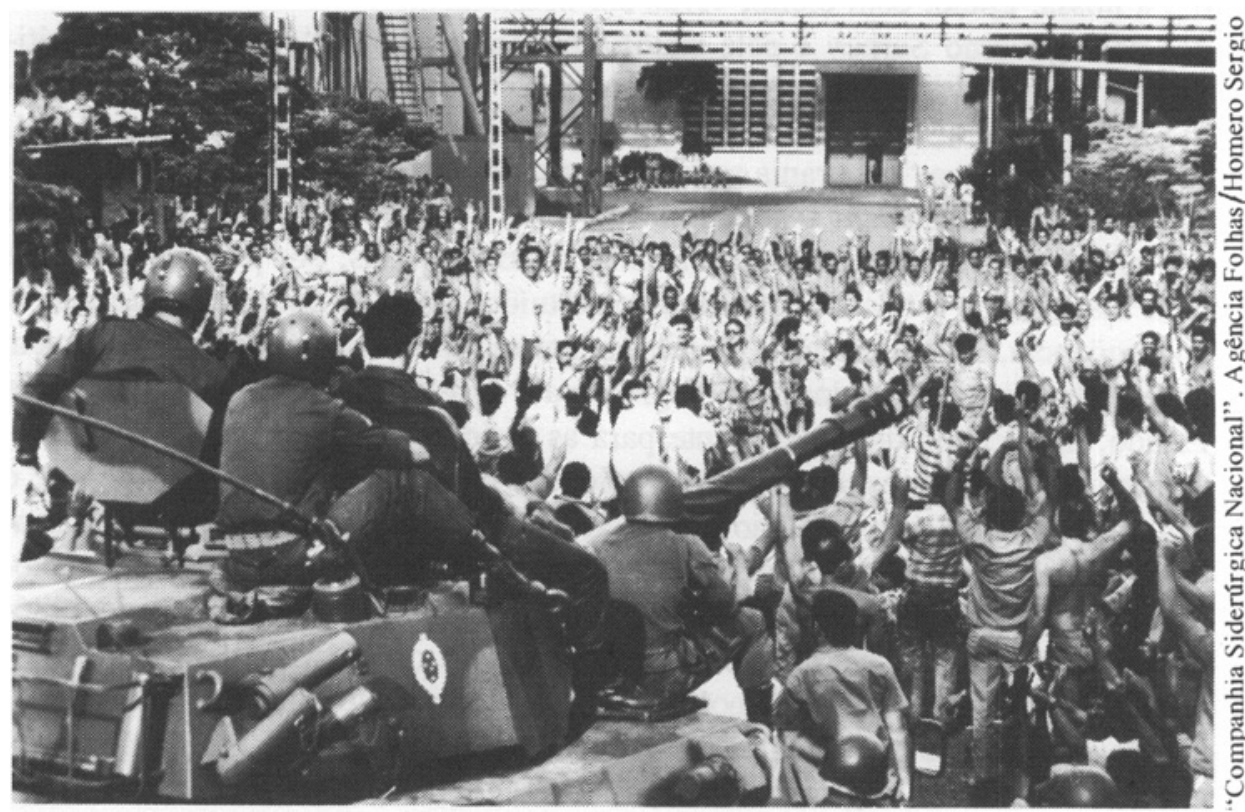

Como se sabe, a participação dos positivistas no Governo Provisório, longe de pesar decisivamente nos rumos do novo regime, reduziu-se à efêmera e tumultuada passagem de Benjamin Constant pelo Ministério da Guerra, de onde foi discreta e constrangedoramente demitido por inépcia e, em seguida, pelo Ministério de Instrução, Correios e Telégrafos (criado ad hominem para não deixar fora do Governo Provisório o principal articulador da conspiração republicana), do qual se demitiria a 18 de janeiro de 1891, já em seu leito de morte,

A fórmula canônica dos manuais de história pátria, de que o marechal Deodoro proclamou a

República, é uma maneira elegante de assinalar que a

República, entre nós, nasceu de um golpe militar. e pela ainda mais efêmera (e também conturbada) passagem de Demétrio Ribeiro pelo Ministério da Agricultura, que, como observa Magalhāes Junior (1957, p. 132), logo ao tomar posse "dera a medida de suas intençōes, declarando, em discurso" ser "positivista ortodoxo" e esperar "que suas idéias nāo encontrassem resistência no Ministério. Defendeu, também, o estabelecimento de uma ditadura permanente, contrariando o ponto de vista dos republicanos, em geral, que queriam estruturar o regime à sombra de uma constituição".

Não foi, portanto, na forma da doutrina elaborada pelos discípulos brasileiros de Augusto Comte que a ditadura provisoria dos chefes do golpe republi- 
cano manifestou inclinaçōes para se cristalizar como ditadura militar ou ditadura tout court, mas sob a forma, ideologicamente mais anódina e politicamente muito latino-americana, do presidencialismo ditatorial. $O$ presidencialismo se torna ditatorial quando se sobrepōe à representação nacional (quer ela se chame Parlamento, Congresso, Assembléia Nacional, quer seja unicameral ou bicameral) e, escapando a seu controle, se erige em poder autônomo. A autonomização do Executivo não correspondia a um desígnio político do marechal Deodoro: não se registrou nenhuma iniciativa sua no sentido de postergar ou entravar $o$ processo constituinte. $\mathrm{Na}$ verdade, foi do Congresso, no dia mesmo de sua instauração (15 de novembro de 1890), que partiu o questionamento dos poderes do chefe do Govemo Provisório no período que entāo se iniciava. Os próprios termos em que foi colocado nos remetem à força repetitiva da inércia jurídico-institucional característica de uma cultura política gelatinosa (os ufanistas e outros conformistas preferem falar em "conciliação" e em "moderação") como o é a nossa. Estão, com efeito, vivos em nossa memória os argumentos utilizados pelo governo Sarney e pela maioria parlamentar dita "Aliança Democrática" que o apoiava, no sentido de restringir a "soberania" do Congresso Constituinte eleito a 15 de novembro de 1986 à elaboração do texto constitucional. O fato de que uma "soberania restrita" constitua uma contradictio in adiecto (o poder capaz de restringir o soberano é o verdadeiro soberano) não impediu que prevalecesse esta concepçäo logicamente aberrante, mas, por isso mesmo, apta para assegurar a tutela dos poderes constituídos sobre o poder constituinte. A conseqüência, à qual estamos presentemente confrontados, é a contradição sem síntese dialética entre a instância legislativa e a instância executiva do poder de Estado, deslocando dramaticamente para as eleiçōes presidenciais de 15 de novembro de 1989 as expectativas - duvidosas porque providenciais - de que o candidato ungido pelo sufrágio universal triunfe das catástrofes que nos ameaçam e promova a salvação nacional. A semelhança entre a mecânica institucional do "conflito de soberania" que atravessou o processo constituinte de 198688 e a daquele que, um século antes, atravessara o de 1890-91, é evidente o bastante para que a consideremos como sintomática, isto é, como expressão de causas objetivas e persistentes. A reconstituição, ainda que esquemática, do confronto entre o Congresso Constituinte de 1890-91 e o Governo Provisório confirma-o eloqüentemente. Insistamos apenas, antes de apresentá-la, em que não esperamos de uma analogia histórica mais do que ela pode nos dar: a convicção de que a semelhança entre os processos políticos que estamos comparando dificilmente poderia ser considerada como fortuita e de que, portanto, muito provavelmente, revele alguma característica arraigada do que, faute de mieux, estamos chamando de nossa cultura política. Para maior clareza da argumentação analógica que segue, apresentaremos separadamente os pontos pertinentes de semelhança entre os dois processos constituintes que consideramos.

\section{a) Elaboração de um anteprojeto por uma Comissão de Juristas}

Antes que o novo regime completasse três semanas, a 3 de dezembro de 1889, o Governo Provisório nomeou uma comissão de cinco juristas, presidida por Saldanha Marinho, para elaborar o projeto da Constituição republicana, na 
verdade um anteprojeto, pois seria reelaborado pelo próprio Governo Provisório, notadamente por Rui Barbosa. A analogia com a Comissão Arinos é relevante: em ambos os casos, a primeira versão do texto constitucional foi elaborada por personalidades designadas pelo Executivo. Já o encaminhamento desta versão inicial foi diferente. $O$ texto da Comissão de Juristas de $1889-90$, revisto e corrigido pelo Governo Provisório, foi promulgado por decreto de 22 de junho de 1890, ad referendum do futuro Congresso Constituinte. $O$ da Comissão Arinos, no melhor dos casos, terá contribuído, com seu liberalismo avançado, para fixar um parâmetro político aos futuros constituintes, mas, enquanto tal, o texto por ela produzido foi arquivado, tendo o Congresso Constituinte retomado, ex nihilo, o labor legiferante. De qualquer modo, nos dois casos, a criação, por ato do Executivo, de uma comissão de notáveis, incumbida de dar início ao processo constituinte, remete à sintomática persistência, em nossa cultura política, daquela disjunçāo entre o "país legal" e o "país real" na qual se apoiou Oliveira Vianna para diagnosticar o caráter utopicamente liberal de nossas instituiçōes jurídico-políticas, contrastando aberrantemente com o caráter clânicooligárquico de nossas instituiçōes sociais. Com efeito, em 1890, como em 1986, o corpo eleitoral, vale dizer, a cidadania enquanto detentora eminente do poder soberano, não participou de nenhuma das decisões a respeito do modo de elaboração da nova Constituição. Questão secundária, de pura forma? Ou, conforme a expressão de um jurista liberal a propósito da reivindicação de um plebiscito para decidir se o corpo constituinte que seria eleito a 15 de novembro de 1986 teria a forma de uma "Assembléia exclusiva" ou de um Congresso tradicional, "a questão não é verdadeira, mas antes semântica, mais uma ilusão!" (REALE Jr., 1985, p. 3) ${ }^{13}$. Deixando de lado a contraposiçáo vulgar entre a verdade e a semântica, fica patente neste desprezo pela forma aquele aspecto gelatinoso de nossa cultura política (ou, mais precisamente, da cultura política de nossas "elites") que integra o quadro sintomático da esquizofrenia institucional obsessivamente diagnosticada por Oliveira Vianna. $O$ que é afinal a lei senāo a forma de universalidade em que se exprime o "bem comum", a "vontade geral" ou o "interesse coletivo"? Na questão que nos ocupa, o desprezo pela forma é tanto mais grave pois se trata da forma de expressão da soberania popular numa sociedade onde este princípio, que sintetiza a essência da democracia, existira apenas como fórmula retórica no arsenal ideológico das "elites" liberais. No momento em que, após 21 anos de usurpação do poder soberano da cidadania pela corporação armada do Estado, abria-se enfim a possibilidade objetiva de instaurar uma ordem legal que tivesse sua origem na expressão da vontade coletiva do povo brasileiro e não no arbítrio dos "poderes constituídos", sustentar, como o fez o aludido jurista, sob o falacioso pretexto de que os partidários da "Assembléia exclusiva" estavam "denegrindo e aviltando o Congresso Nacional", que se deveria negar aos cidadãos o direito de decidir, através de um plebiscito, qual a forma idônea que deveria assumir a delegação popular do poder constituinte ao corpo de representantes encarregado de elaborar a Constituição, é retomar as mais deletérias tradiçōes de nosso liberalismo, tal como foi perversamente adaptado pelas oligarquias agrárias da "República Velha" às condiçōes concretas de exercício de sua hegemonia sobre a socieda-

13 O autor $\varepsilon$ suficientemente conhecido como jurista; sua vinculaçāo à cúpula peemedebista durante o processo constituinte torna seu ponto de vista particularmente significativo. 
de brasileira de então. Se as instituiçōes codificadas na Constituição de 1946 configuraram um avanço sem precedentes em nossa história no rumo da instauração de um sistema liberal-democrático, foi em larga medida porque introduziram no Brasil uma forma credível de expressāo da vontade popular, a saber, um processo eleitoral expurgado daquela sistemática e escandalosa manipulação a que se submetia, na "República Velha", o exercício do direito do voto. Opor a forma ao conteúdo, argumentando que "o substancial está no conteúdo da nova Constituição" (REALE Jr., 1985, p. 3) implica em negar o princípio mesmo da legalidade democrática, tal como formulado, sob inspiração direta de Rousseau, no artigo 4 da Constituição democrática de 24 de junho de 1793, que marcou o auge da Revolução Francesa: "a lei é a expressão livre e solene da vontade geral". O argumento de fundo do artigo "Plebiscito" de Miguel Reale Jr., (1985, p. 3)é o de que qualquer crítica ou restrição ao Congresso é um golpe contra a democracia, "cujo alicerce básico está em instituiçōes respeitadas, mormente o Legislativo". Como se as instituiçōes devessem ser respeitadas por estarem instituídas e não por se mostrarem dignas de respeito! Além de seu caráter manifestamente corporativo, $o$ argumento tem servido para acobertar toda sorte de abusos e corrupçōes cometidos por membros dos corpos legislativos municipais, estaduais e federais que interpretam seus mandatos como investimentos custosos que devem ser rentabilizados por quaisquer métodos. Contra as apologias mal intencionadas ou conformistas dos privilégios parlamentares, nunca será demais repetir que não é a mera existência do Parlamento, mas o controle pelo povo da conduta de seus representantes que garante a democracia. $O$ conteúdo de um ordenamento jurídico pode ser melhor ou pior; não será democrático se a forma política de sua elaboração não corresponder ao princípio da soberania popular. Sem dúvida, e esta seria a interpretação a mais otimista da imposição pelos poderes constituídos de uma Constituinte congressual, não se pode excluir a priori a hipótese - ardorosamente defendida entre nós por Oliveira Vianna - de uma via autoritária para a democracia. Mas que então, ao menos, não se violente a semântica apresentando como democrático um processo constituinte que começou - afastando o plebiscito sobre a "Assembléia exclusiva" e terminou - afastando o plebiscito sobre o conteúdo final do texto constitucional - recusando a participação direta do corpo eleitoral nas questōes as mais decisivas. Mais justo será dizer, tanto a propósito da designação, pelo Executivo, da Comissão Arinos, quanto da imposição, pelo Congresso eleito em 1982, de uma Constituinte congressual, que corresponderam a uma etapa, sem dúvida avançada, daquela transiçāo liberal militarmente controlada cuja origem remonta à "política de abertura". lançada em 1974 pelos generais Emesto Geisel e Golbery do Couto e Silva. As limitações impostas à participação direta dos cidadãos na elaboração da Constituição chamada a instaurar a democracia no Brasil decorrem, portanto, do próprio carater conservador da transiçāo, isto é, de uma evoluçāo para a democracia sem ruptura institucional com a ditadura.

\section{b) Limitação da "soberania" do Congresso Constituinte à elaboraçâo do texto constitucional}

A questão se colocou em termos sintomaticamente semelhantes nos dois processos constituintes considerados. Não insistiremos em que, no plano dos princípios, a idéia de uma soberania limitada encerra uma contradição lógica.
(O) presidencialismo se torna ditatorial quando se sobrepōe à representaçāo nacional (quer ela se chame Parlamento, Congresso, Assembléia Nacional, quer seja unicameral ou bicameral) e, escapando a seu controle, se erige em poder autônomo. 
Tanto em 1890-91 quanto em 1986-88, foram correntes minoritarias, respectivamente os positivistas "ortodoxos" e os partidários da "Assembléia exclusiva", que puseram em evidência tal contradição; aqueles preconizando a ditadura do Executivo, estes, ao contrário, defendendo a plena transparência democrática da delegaçāo de poderes constituintes de seus detentores originários (os cidadāos) a seus representantes. Uns e outros foram marginalizados, o que evidentemente nāo impediu a contradição não-resolvida de eclodir obliquamente na forma de conflito de soberania entre o Congresso e a Presidência.

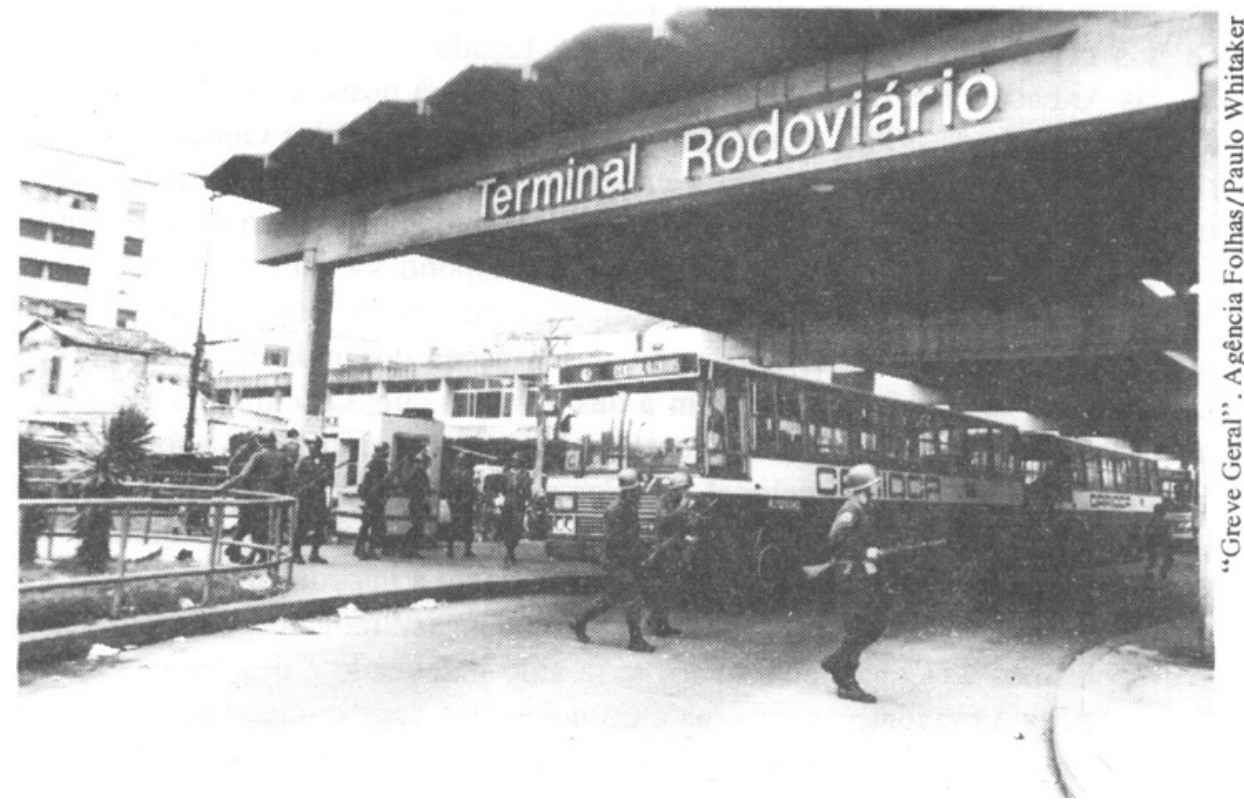

Em 1890, o conflito surgiu no mesmo dia em que o Congresso foi solenemente instalado. Logo na abertura dos trabalhos, numa troca de amabilidades com Deodoro, o Congresso designou uma comissāo para saudá-lo no palácio presidencial e entregar-lhe uma moção na qual notadamente procurava contornar o latente conflito de soberania do mesmo modo como seria contornado um século depois: restringindo as atribuiçôes dos constituintes à elaboração do texto constitucional. Nem todos os membros do Congresso concordaram com tal soluçāo. Américo Lobo propós outra, na qual o Congresso Nacional se reconhecia "desde já o único competente para exercer o poder legislativo" (MAGALHÃES JUNIOR, 1957, v. 2, p. 234) ${ }^{14}$. Um pouco mais moderado, Leite Oiticica propôs um decreto no qual o Congresso se atribuía "o direito de examinar os atos do Governo Provisório" (id. ibid., p. 234-35). Tampouco foi aprovado, mas, como pertinentemente observa Magalhäes Jr., constituiu, como o de Américo Lobo, "o ponto de partida da cisão futura entre o Poder Legislativo e o Poder Executivo e da crise de novembro de 1891" (id. ibid., p. 235).

$\mathrm{Na}$ "Nova República", a indefinição em que fora deixada a questão das competências respectivas do poder constituinte e dos poderes constiturdos resultara de um pacto secreto entre os dirigentes da "Aliança Democrática" com as cúpulas militares e, mais exatamente, com os altos mandos militares não

14 Para uma discussåo circunstanciada deste primeiro e tenso contato entre os dois poderes, cf. p. 229-35. 
comprometidos com a entourage de Figueiredo, isto é - para mencionar apenas aqueles mais visivelmente envolvidos em surdas e duvidosas manobras continuístas e de sabotagem da "transição" -, os generais Valter Pires, Otavio de Medeiros e Newton Cruz. Embora conciliábulos desta natureza não costumem ser registrados em ata, pode-se afirmar com segurança, como de resto o fizeram, na época, fontes sérias da imprensa ${ }^{15}$, que 0 aludido pacto, definitivamente concluído num encontro entre Tancredo Neves e o general Leônidas Gonçalves, comportava o compromisso assumido pelo chefe da "Aliança Democrática" de se abster de qualquer iniciativa suscetível de abalar a estabilidade dos organismos essenciais do poder de Estado, a começar pelas próprias Forças Armadas. Em troca, estas garantiriam apoio à posse de Tancredo Neves a 15 de março de 1985. A designaçāo do general Leônidas Gonçalves como Ministro do Exército constituiria a caução deste acordo. Não experimentamos inclinação alguma para superdimensionar o aspecto conspirativo da ação política. Se a iniciativa de Tancredo Neves não correspondesse a uma vontade majoritária no interior da "Aliança Democrática", a posição do bloco governamental no Congresso Constituinte a respeito das funçōes dos militares não teria se harmonizado tão perfeitamente com a das próprias cúpulas militares. Esta harmonia, preestabelecida, mas conveniente para ambas as partes, abrangia não somente o estatuto constitucional das Forças Armadas, mas também a questão liminar e decisiva do conteúdo político do próprio processo constituinte (a recusa da "Assembléia exclusiva" visava obviamente a impedir que este processo assumisse características que favorecessem mudanças "radicais" ou indesejados "revanchismos"). Como, entretanto, teria sido indelicado e deselegante amputar, explícita e preventivamente, as atribuiçōes dos constituintes, optou-se pela gelatinosamente tradicional solução de passar por baixo das questōes de princípio, deixando que o curso das circunstâncias e, quando necessário, 0 argumento da força, se encarregassem de colocá-las e de resolvê-las.

A 15 de novembro de 1986, ofuscado pela luz ainda resplandecente de uma estrela já morta, o corpo eleitoral votou maciçamente nos candidatos do PMDB-PFL ao Congresso Constituinte, na esperança, cruelmente desmentida nos dias seguintes, de estar elegendo o Congresso do Cruzado I ou, mais exatamente, de estar reelegendo a política econômica da estabilização monetária com expansão da produção e do consumo interno. A rapidez com que a "liberação dos preços" dissipou esta ilusão de ótica, arruinando a credibilidade da "Aliança Democrática" e mais ainda a de Sarney, repercutiu fortemente nas relaçōes entre o Congresso e a Presidência. Neste ambiente de desmoralizaçāo partilhada, as mesquinhas ambiçōes do pateticamente medíocre político maranhense, guindado à chefia da "Nova República" por um concurso nefasto de circunstâncias, provocaram o primeiro confronto grave entre o poder constituído e o poder constituinte. A efêmera euforia do "Cruzado I" trouxera ao chefe de Estado a esperança de se eximir de seu compromisso solene de só aceitar um mandato presidencial de quatro anos. Desfeitas as ilusōes, assaltou-o o compreensível temor de que, no afã de dissociar sua imagem da imagem irremediavelmente desgastada do governo, o PMDB fizesse causa comum com a oposiçāo,

$15 \mathrm{Na}$ Introdução ao livro A tutela militar, de nossa co-autoria, em colaboração com Wilma Peres Costa e Eliezer Olıveira, mencionamos o episodio e a fonte de imprensa pertinente, ver: p. 15, nota 4 e p. 18 . 
A 15 de novembro de 1986, ofuscado pela luz ainda resplandecente de uma estrela já morta, o corpo eleitoral votou maciçamente nos candidatos do PMDB-PFL ao Congresso Constituinte...

decidida em cobrar-lhe a promessa de limitar a quatro anos o dom de sua pessoa à nação. Face a esta inquietadora eventualidade, o Executivo ativou ampla gama de pressōes sobre o Congresso, desde a distribuição de sinecuras até o recurso ao "argumento da força". Por se tratar de eventos que integram nosso presente histórico, dispensamo-nos de referir circunstanciadamente as peripécias da "guerra psicológica" (o jargāo da ESG se aplica aqui perfeitamente) movida desde os bastidores do poder de Estado com o objetivo de fazer o Congresso deliberar com urgência sobre a duração do mandato presidencial e deixar claro que nem o Presidente, nem a cúpula militar aceitariam o mandato de quatro anos. $O$ desfecho foi precipitado pelo pronunciamento (no duplo sentido do termo) de 18 de maio de 1987, quando, numa declaração difundida em tom melodramático em cadeia nacional de rádio e de televisão, o inquilino do Palácio do Planalto "informou" ao país que "decidira" ali permanecer durante cinco anos. Um gesto tāo audacioso num personagem mais propenso a tirar vantagem das circunstâncias do que a forçá-las sugere uma explicação em termos de ventriloquia política: Sarney movia os lábios, mas quem falava era o general Leônidas Gonçalves ${ }^{16}$.

Na verdade, o pronunciamento de 18 de maio de 1987 violou não somente as atribuiçōes do poder constituinte, mas o próprio ordenamento legal ainda em vigor naquele momento, outorgado pela ditadura militar com base nos poderes discricionários do Ato 5, a saber, no caso, o dispositivo do chamado "pacote de abril" (de 1977) que estendeu para seis anos a duraçāo do mandato presidencial, modificando o dispositivo da também outorgada Carta de 1969, que o fixara em cinco anos. Mesmo, portanto, que fosse vedado ao poder constituinte tocar na legislação em vigor até a promulgação da nova Constituição (hipótese que o próprio Sarney reconhecera como falsa ao exigir que o Congresso lhe fixasse a duração do mandato), a opção seria de quatro anos (compromisso político solene de Tancredo Neves e de Sarney) ou seis anos (legislaçāo em vigor), mas nunca de cinco anos. A bem da objetividade diga-se que, postos diante da chantagem política de 18 de maio, muitos constituintes do centro somaram-se aos da direita, seguindo Ulysses Guimarães, para legalizar a posteriori a manobra ilegal de Sarney.

Ao dirimir em seu favor o conflito de soberania que o opunha ao Congresso, colocando-o, pelo argumento da força, diante do fato cónsumado de que decidira não arredar pé da Presidência antes de 15 de março de 1990, Sarney, embora perseguisse objetivos demasiado subalternos para sequer fazê-lo merecedor do epíteto de "Luis Bonaparte tupiniquim" com que o gratificou, na ocasiāo, o jornal $O$ Estado de $S$. Paulo ${ }^{17}$, serviu de instrumento à reafirmação da supremacia do aparelho coercitivo do Estado (essencialmente a cúpula do Exército e os serviços ditos "de segurança" por ela controlados) sobre os representantes da nação. Como em 1890-91, também em 1986-88 a ambigüidade em que foi sem dúvida intencionalmente deixada a questão da instância soberana do poder de Estado criou o contexto propício às manobras usurpatórias. Onde falta

16 Este episódio está comentado mais circunstanciadamente em nosso estudo "O argumento da força" em: As Forças Armadas no Brasil, 1987, p. 43-4.

17 A fórmula citada 6 o título do editorial de $O$ Estado de S. Paulo de 20 de maio de 1987. O Jornal do Brasil de 19 de maio noticiara o pronunciamento presidencial com fórmulas igualmente incisivas, constatando, notadamente, que "Sarney ignora Constituinte e fixa mandato". 
uma solução legítima ou ao menos legal, o terreno está aberto para a solução de força. O éthos gelatinoso do jeitinho brasileiro e o éthos truculento do golpismo militar são velhos cúmplices, a cuja parceria devemos, em boa medida, a atrofia, em nossa cultura, da noção de cidadania democrática e sobretudo de seu pressuposto ético fundamental: a compreensão, por parte de cada cidadão, de que a lei é a forma adequada de expressāo de seu interesse coletivo, vale dizer, de seu interesse enquanto membro da coletividade.

\section{c) Persistência do conflito entre a Presidência e o Congresso após o término do processo constituinte}

Quando foi empossado o primeiro Congresso republicano, estava em vigor, ad referendum, desde 22 de junho de 1890, o texto constitucional esboçado pela Comissão de Juristas, revisto e corrigido por Rui Barbosa em nome do Governo Provisório. Embora, como notamos, tenha eclodido já a 15 de novembro de 1890, o conflito entre o Congresso e o Presidente não atingiu dimensōes críticas ao longo dos trabalhos dos constituintes, que se estenderam até 24 de fevereiro de 1891. Contrariamente ao que ocorreria cem anos depois, a questāo do mandato presidencial nāo envolvia insidiosas ambigüidades. Caberia ao Congresso Constituinte eleger o presidente, cujo mandato expiraria a 15 de novembro de 1894, conforme estipulado no art. $43, \S 4$ da nova Constituição. Acresce que Deodoro chegara à chefia do governo montado no próprio cavalo e não na garupa de um cavalo alheio, como ocorreria ao vate dos Marimbondos de Fogo. Compreende-se assim que as tensões entre o Executivo e o Legislativo tenham se polarizado em torno da forte personalidade do marechal Deodoro, cujo desgaste, sobretudo a partir do momento em que fez do Barão de Lucena seu primeiro-ministro de fato, acentuou-se a ponto de isolá-lo mesmo em relação à corporação militar. Como se sabe, na eleição presidencial de 25 de fevereiro de 1891, o Congresso prestou ao proclamador da República uma duvidosa homenagem: assegurou-lhe a vitória (com 129 votos contra 97 para seu adversário Prudente de Morais), mas recusou seu candidato a vice, o almirante Wandenkolk, preferindo o candidato da oposição, Floriano Peixoto, por 153 votos contra 57. Que o temperamento atrabiliário de Deodoro tenha contribuído para agravar o conflito institucional que acabaria levando ao confronto aberto e à frustrada tentativa de resolvê-lo pelo ato de força de 3 de novembro de 1891 I tissolução do Congresso e proclamação do estado de sítio), é incontestável. Mas o conflito de competência e, em última instância, de soberania entre a Presidência e o Congresso envolvia interesses e problemas muito mais amplos do que as peculiaridades psíquicas do chefe do Estado. A proclamação da República, ou, mais exatamente, a queda da Monarquia, colocara na ordem do dia a questão da formação de um consenso hegemônico articulando os interesses dominantes, vale dizer, de uma aliança política capaz de assumir duravelmente a direçāo do País. Arriscamos a hipótese de que o período de cinco anos compreendido entre 15 de novembro de 1889 e 15 de novembro de 1894 correspondeu à explicitaçāo e ao confronto de dois projetos hegemônicos - nenhum dos quais se identificava, nem mesmo simbolicamente, à pessoa do proclamador da República. Um destes projetos passou à história pátria sob o epíteto (que para alguns de seus defensores constituiu também uma auto-identificação e portanto uma autodesignação política) de jacobino. Mas foi o outro - ao qual nossa história
O ethos gelatinoso do jeitinho brasileiro e o ethos truculento do golpismo militar são velhos cúmplices, a cuja parceria devemos, em boa medida, a atrofia, em nossa cultura, da noção de cidadania democrática... 
atribuiu um epíteto mais banal, aliança do café - que se impôs como forma viável de dominação política do Brasil agroexportador.

Examinar a história do enfrentamento destes dois projetos, cujo embate decisivo ocorreu durante os três anos do governo, levar-nos-ia demasiado longe desta nossa análise comparativa do recurso ao argumento da força nos processos constituintes de 1890-91 e 1986-88. Notaremos apenas que o florianismo, enquanto movimento político onde confluíram o positivismo e o jacobinismo, embora tenha carecido de fôlego histórico (sobreviveu, enquanto oposição radical, durante o primeiro governo civil da República, que, não por acaso, correspondeu à instauração da aliança histórica dita do cafe), constituiu a primeira versão histórico-concreta, no Brasil, do programa (tosca e ambiguamente formulado, é verdade) nacional-popular, ou, como dirão seus detratores, dentro e fora da Universidade, xenófobo-populista.

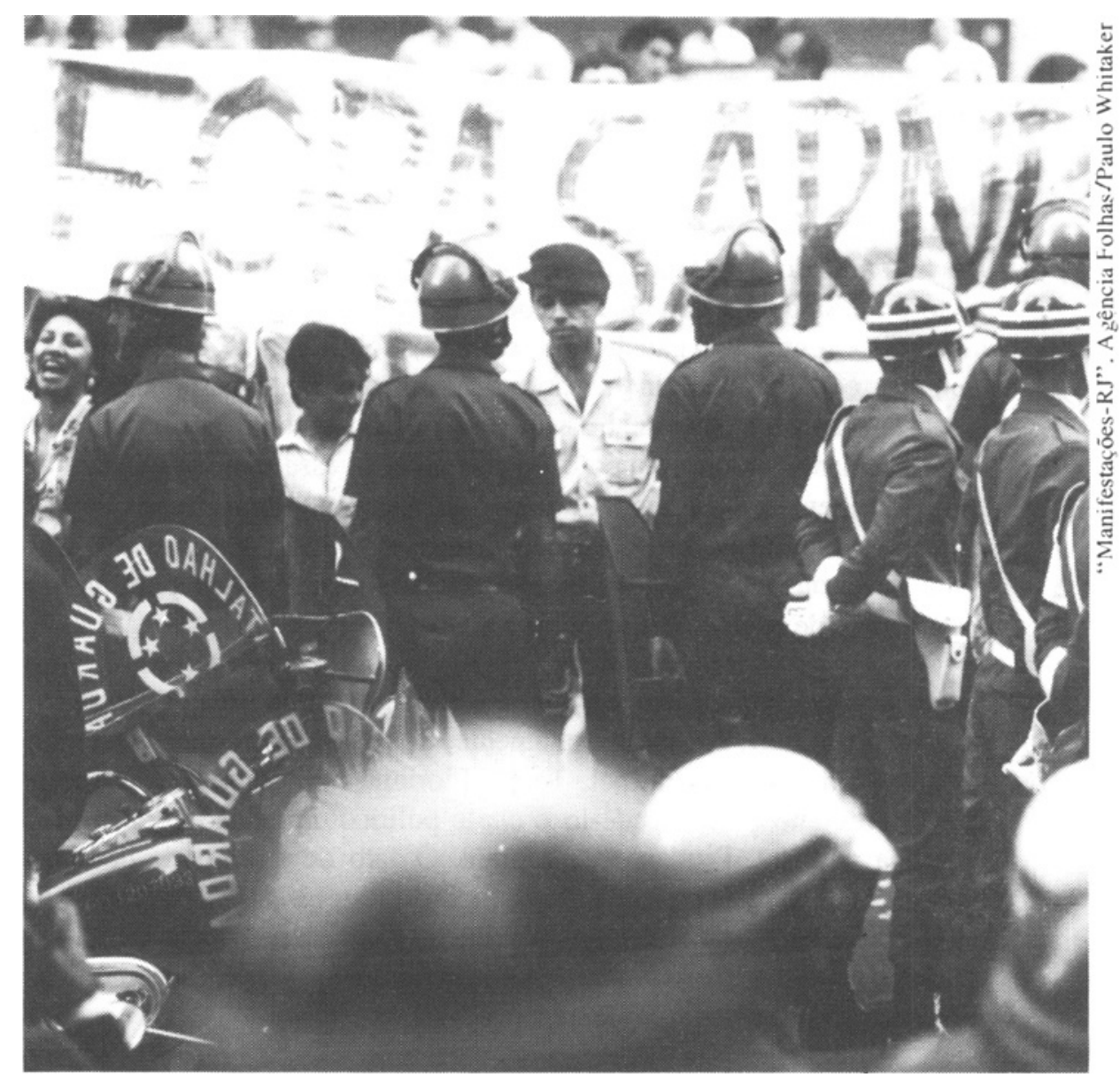

O uso indiscriminado e depreciativo do termo "populismo" para (des)classificar ampla gama de movimentos políticos, que só têm em comum o fato de terem sido julgados merecedores de tal imputação a partir de analogias superficiais ou de tipologias escolásticas, nos incita à cautela ao avaliar o significado histórico-social do jacobinismo brasileiro. É geralmente reconhecido pelos historiadores seu caráter popular. Edgard Carone enumera "pequenos funcionários públicos, baixa oficialidade do Exército e forças públicas, inte- 
lectuais pequeno-burgueses" na composição social do movimento jacobino, mas dela exclui enfaticamente os operários (CARONE, 1971, p. 154) ${ }^{18}$. A admiração (politicamente simpática) de Carone pela classe operária, que o faz afirmar nāo ser "nunca de operários" (id. ibid, p. 154) a composiçäo social do jacobinismo, parece, no caso, haver violentado os fatos. É, sem dúvida, desagradável constatar que a primeira versão política do "nacional-popular" em nossa história republicana comporte abominações como as engendradas na pluma duvidosa do sr. Martyr ${ }^{19}$, e em especial, que a causa nacional tenha sido ativada, naquele contexto, por métodos tão espúrios. Nem por isso se pode ou se deve assimilar nacionalismo à xenofobia, nem popular a populismo.

De qualquer modo, para fundamentar historicamente nossa hipótese, o que nos importa é assinalar:

a) o efeito de ocultamento que o conflito entre Deodoro e o Congresso exerceu sobre o conflito mais fundamental entre o Executivo (como instrumento de uma ditadura nacional-popular, tal como se delineou no ideário florianista) e o Legislativo (como instância onde se articulava o consenso hegemônico dos representantes da ordem agrária);

b) o efeito de desocultamento exercido pela presidência de Floriano e, mais exatamente, pela aliança antiflorianista dos ultrafederalistas do Rio Grande do Sul e da Armada rebelde às ordens de Custódio de Melo e de Saldanha da Gama: embora esta aliança, além de fortemente heteróclita (entre um gaúcho guerrilheiro, politicamente quase secessionista, como Gumercindo Saraiva e um almirante assumidamente monarquista como Saldanha da Gama, o único vínculo político era o antiflorianismo), muito pouco ou quase nada tivesse em comum com a fração dirigente da oligarquia agrária paulista (os "republicanos históricos"), o fato de haver polarizado os adversários do govemo de Floriano suscitou a polarização oposta de seus partidários e portanto a clarificação de suas posiçōes políticas;

c) o fato de que embora tenha amplamente triunfado de seus adversários no terreno militar, ou, mais exatamente, dos adversários que quiseram derrubá-lo da presidência pela força, Floriano não conseguiu impedir que fosse eleito para sucedê-lo o chefe político da reação agrário-oligárquica paulista, Prudente de Morais. $O$ fato de terem sido companheiros de chapa nas eleiçöes presidenciais indiretas de 25 de fevereiro de 1891 confirma, de resto, nossa primeira hipótese: afastado Deodoro da cena política, clarificou-se o conflito entre o projeto hegemônico jacobino e o federalista agroexportador;

18 No entanto, Suely Robles Reis de Queiroz, em seu minucioso trabalho Os Radicais da República, 1986, menciona, entre outros, o epiśdio em que Deocleciano Martyr (do qual o mínimo que se pode dizer é que estava mais para martirizador do que para martirizado), editor de $O$ Jacobino e autor de virulentas e as vezes odiosas diatribes xenófobas, foi homenageado por "um grupo de operários" que lhe ofereceu um retrato no qual Deocleciano "de pe, muleta em uma mão e um vergalho de quatro pernas noutra, fustiga um covarde labrego, barbado e careca, que, a seus pés, implora misericórdia" (op cit., p. 102-103). sinônımo de "supremacia", sem preocupação de rigor teórico. 
d) o fato de que nem o prestígio pessoal de Deodoro - já bem desgastado, é verdade - nem o de Floriano - intacto - puderam se contrapor com eficácia ao consenso hegemônico em articulação no Congresso remete à correlação de forças entre o Exército e a classe dominante. A força concentrada da corporação das armas mostrou-se muito menos poderosa, enquanto instrumento de dominação política, do que a força dispersa dos donos da terra. Donde a supremacia do Congresso (enquanto instância de articulação política nacional dos centros regionais do poder agrário) sobre o Executivo (enquanto instância detentora do controle imediato do aparelho de Estado federal).

À supremacia do Congresso enquanto instrumento e expressão do consenso hegemônico das oligarquias rurais da República Velha se contrapõe o predomínio do Executivo no processo constituinte de 1986-88. A contraposição não é, entretanto, frontal, ou, para usar a terminologia estruturalista, não há uma rigorosa simetria inversa entre os dois processos. A rigor, poder-se-ia mesmo discernir uma semelhança direta entre ambos: a partir de uma supremacia assumida do Executivo, investido de poderes ditatoriais (o Governo Provisório de Deodoro; o ciclo dos generais de 1964 a 1985), a evolução vai no sentido do fortalecimento do Congresso e portanto da limitação dos poderes presidenciais. A diferença concerne ao resultado histórico dos dois processos. Estamos convencidos, no referente à Velha República, da decisiva importância do Congresso, menos em suas funçōes típicas de poder legislativo supremo e de instância de controle do Executivo do que de centro de articulaçấo das oligarquias estaduais e, através do peculiar instituto dito da "verificação dos poderes", de colégio eleitoral superior, dotado de "soberania absoluta" (CARONE, 1972 , p. 306) ${ }^{19}$ para designar os mandatários do poder executivo. No léxico da classificaçāo das formas de governo e de soberania elaborado por Bodin, diríamos que se trata de uma monarquia eletiva controlada pela aristocracia, ou melhor, pela oligarquia nural. Quanto à "Nova República"; o resultado histórico está ainda indefinido, mas sabemos todos que a forte autonomia de que dispóe a corporação militar no interior do aparelho de Estado, bem como a de que dispōe o Estado face à sociedade confere-lhes - mais àquela do que a este - um poder de veto tutelar suscetível de se transformar, numa situaçāo de crise política maior, em intervenção golpista. Se o Congresso conseguiu, apesar dos pesares, fortalecer-se face à Presidência, ao menos no terreno de suas atribuiçōes constitucionais, a decomposição orgânica e a desmoralização política precoces dos dois partidos que compuseram a maioria constituinte (PMDB e PFL) revelam sintomas inequívocos da profunda crise de representação partidária em que permanece mergulhada a sociedade brasileira desde o golpe de 1964, ou, mais

... sabemos todos que a forte autonomia de que dispōe a corporação militar (...) confere-Ihes um poder de veto tutelar suscetivel de se transformar, numa situaçāo de crise polftica maior, em intervençāo golpista. exatamente, desde a supressão, por força do Ato Institucional no 2, dos partidos políticos forjados nas duas décadas precedentes, a respeito dos quais, por mais críticos que sejamos, temos de reconhecer consistência bem maior do que a daqueles direta ou indiretamente oriundos da ditadura militar (PDS, PMDB e suas respectivas cisōes, PFL e PSDB). A consequêencia mais visível do divórcio entre representação parlamentar e cidadania é a transferência da legitimidade representativa para os mandatos executivos e sobretudo para as eleições presidenciais. Constatada a incapacidade dos grandes partidos para exercer a função mediadora entre a sociedade e o Estado e, portanto, de constituir o instrumento 
de controle pelos cidadãos do poder político e de sua máquina burocrática, criam-se as condiçōes para a "ilusão bonapartista" das massas, tal como foi insuperavelmente descrita, a propósito da França de 1848, no 18 Brumário de Karl Marx. Em nosso caso, se o "Bonaparte" em questão for do agrado das cúpulas militares, a manutenção do atual equilibrio institucional entre a Presidência e o Congresso dependerá de sua performance governamental: na hipótese de fracassar e se desmoralizar como Sarney, a estabilidade do regime definido na Constituição de 1988 dependerá de uma difícil - a curto prazo, pelo menos, já que a médio prazo é lícito ser otimista, embora, como disse um economista célebre, a médio prazo estaremos todos mortos - recuperação da credibilidade dos sistemas de partidos (o fato de que haja, hoje, pequenos e médios partidos politicamente crediveis não basta). Se o hipotético "Bonaparte" acertar, isto é, se seu governo não for nem um patético fiasco como o de Jânio Quadros em 1961, nem uma viscosa gelatina cuja única bússola é a "lei de Gerson", como o de Sarney, as perspectivas de estabilização seräo maiores, mas a evolução democrática, tanto no sentido formal I fortalecimento dos partidos enquanto órgãos da cidadania) quanto no material (reformas sociais que suprimam a miséria e atenuem as desigualdades) ficará bloqueada. Enfim, a hipótese de um "Bonaparte de esquerda", de um "cesarismo progressivo" como diria Antonio Gramsci, é a mais dramática, por ser muito alta a probabilidade de um conflito duplamente frontal (com o Congresso e com a corporação militar). A conclusão é óbvia: a probabilidade de uma solução de força é diretamente proporcional à fraqueza do sistema de partidos.

\section{Referências Bibliograficas}

Estado Maior do Exército. 1972. História do Exército Brasileiro. Brasilia e Rio de Janeiro. CARONE, E. 1971. A República Velha II. São Paulo, Difel. - 1972. A República Velha I. São Paulo, Difel.

COSTA, W. P. 1987. Os militares e a primeira Constituição da República. In: A tutela militar. São Paulo, Vértice.

COUTO e SILVA, G. 1967. Geopolitica do Brasil. Rio de Janeiro, José Olympio.

FERREIRA, O. 1985. As Forças Armadas na Constituição. Política e estratégia, III (3), julho/setembro.

FREDERICO de S. 1890. Fastos da ditadura militar no Brasil. Portugal.

MAGALHÃES JUNIOR, R. 1957. O Aprendiz de Feiticeiro. In: ——. Deodoro, a Espada contra o Império. São Paulo, Cia. Editora Nacional, v. 1.

—_. 1957. O Galo na Torre. In: Deodoro, a Espada contra o Império. São Paulo, Cia. Editora Nacional, v. 2.

O ARGUMENTO da força. 1987. In: As forças armadas no Brasil. Rio de Janeiro, Espaço e Tempo.

QUEIROZ, S. R. R. 1986. Os radicais da República. São Paulo, Brasiliense.

REALE JR., M. 1985. Plebiscito. Folha de S. Paulo, 23 de outubro.

SILVA, H. 1972. A República nâo esperou o amanhecer. Rio de Janeiro, Civilização Brasileira.

João Quartim de Moraes é professor de Ciência Política da UNICAMP e participante do Ciclo de Seminários "Cem anos de República: continuidade e mudança", 1989, do IEA. 